\title{
EFFECT OF THE GOVERNMENT INTERVENTION PROGRAM TO THE CROP INSURANCE PARTICIPATION LEVEL
}

\section{Muhammad Ibrahim Rachman ${ }^{* 1}$, Nunung Nuryartono ${ }^{* *}$, Bustanul Arifin ${ }^{* * *}$, and Toni Bakhtiar ${ }^{* * * *}$}

\author{
*) School of Business, IPB University \\ Jl. Pajajaran, Bogor 16151, Indonesia \\ ${ }^{* *}$ Department of Economics, Faculty of Economics and Management, IPB University \\ Jl. Lingkar Akademik, Dramaga Campus, Bogor 16680, Indonesia \\ ${ }^{* * *}$ Department of Agricultural Economics, Faculty of Agriculture, University of Lampung \\ Jl. Prof. Dr. Ir. Sumantri Brojonegoro, Lampung 35141, Indonesia \\ ${ }^{* * * *}$ Faculty of Mathematics and Science, Department of Mathematics, IPB University \\ Jl. Meranti, Dramaga Campus, Bogor 16680, Indonesia
}

\begin{abstract}
In addition to premium subsidies, Indonesia's government implements other intervention programs as a stimulus to boost farmers' participation in Rice Farmers Business Insurance (AUTP). Therefore, this study aimed to investigate the effect of the government intervention program in 2019 that requires participation in AUTP as a prerequisite for redeeming subsidized fertilizer. This study also aimed to ascertain the socioeconomic factors that influence farmers to participate. Meanwhile, primary data were obtained through questionnaires distributed from March 23 to April 6, 2020, and completed by 103 farmers in 14 villages in Sliyeg, Indramayu. The data were analyzed with McNemar Test to determine the effect of farmers' participation in AUTP when the government intervention program was implemented and terminated. Furthermore, Logistic Regression Analysis is used to ascertain the socioeconomic factors that influence farmers to participate. The result showed that the program affects their participation in AUTP. This level is higher when the program is enforced and decreased when terminated. The socio-economics variables that influenced farmers to participate in AUTP when implemented in the government program are land ownership status and land size, while only land size influenced them when terminated.
\end{abstract}

Keywords: agriculture risk, consumer behavior, government stimulus, participation rate, premium subsidy

\begin{abstract}
Abstrak: Selain subsidi premi, pemerintah Indonesia melaksanakan program intervensi lainnya sebagai stimulus untuk mendorong partisipasi petani dalam Asuransi Usaha Petani Padi (AUTP). Oleh karena itu, penelitian ini bertujuan untuk mengetahui pengaruh program intervensi pemerintah tahun 2019 yang mensyaratkan partisipasi dalam AUTP sebagai prasyarat penebusan pupuk bersubsidi. Penelitian ini juga bertujuan untuk mengetahui faktor sosial ekonomi yang mempengaruhi petani untuk berpartisipasi. Sedangkan data primer diperoleh melalui penyebaran kuesioner sejak 23 Maret hingga 6 April 2020 kepada 103 petani di 14 desa di Sliyeg, Indramayu. Data dianalisis dengan Uji McNemar untuk mengetahui pengaruh partisipasi petani dalam AUTP ketika program intervensi pemerintah dilaksanakan dan dihentikan. Selanjutnya, Analisis Regresi Logistik digunakan untuk mengetahui faktorfaktor sosial ekonomi yang mempengaruhi petani untuk berpartisipasi. Hasil penelitian menunjukkan bahwa program mempengaruhi partisipasi mereka dalam AUTP. Tingkat ini lebih tinggi saat program diterapkan dan menurun saat dihentikan. Selain itu, variabel sosial ekonomi yang mempengaruhi petani untuk berpartisipasi saat program dilaksanakan adalah status kepemilikan tanah dan luas lahan, sedangkan hanya luas lahan yang mempengaruhi petani saat program dihentikan.
\end{abstract}

Kata kunci: perilaku konsumen, risiko pertanian, subsidi premi, stimulus pemerintah, tingkat partisipasi

\footnotetext{
${ }^{1}$ Corresponding author:

Email: muhammad.ibrahim@sbm-itb.ac.id
} 


\section{INTRODUCTION}

Rice is one of the most widely consumed grains globally, and Indonesia is the 4th highest consumer after China, India, and Bangladesh. According to USDA (2020), in August 2020, Indonesia consumed 35.4 million metric tons (MT) of rice, a $0.3 \%$ increase from the previous month. For the last four years, consumption has been decreased by $6 \%$. In 2016/17, it was 37.5 million MT and slowly decreased to 37.0 million MT in 2017/18, 36.3 million MT in 2018/19 and 35.5 million MT in 2019/20. In 2020/21, FAO (2020) forecasted that the world rice utilization would be expanded by $1.6 \%$, and Asia, including Indonesia, is envisaged to drive the food-use expansion. In addition to population growth, the implementation of state assistance programs geared towards access to rice by vulnerable consumers could further boost intake. This would mainly be the case in countries such as Bangladesh, Indonesia and especially India, where ample state reserves may encourage officials to extend the duration of expanded publicly subsidized distribution schemes or open market sales launched in the context of the COVID-19 pandemic.

Furthermore, Indonesia is different from the other top three countries because of lower production than national consumption. As of August 2020,34.9 million MT of rice was produced, which is $1 \%$ lower than the national consumption (USDA 2020). The outlook is projected to be more negative in 2020, which was forecasted to experience erratic rains and delayed plantings and lower output below the already reduced 2019 level (FAO, 2020). Meanwhile, Indonesia could witness the largest import increase, as greater market intervention needs by the government. In the context of the COVID-19 outbreak, successive production contractions could sway officials to recur to imports to reconstitute reserves. Also, environmental risk, especially climate change, is one of the biggest challenges because it causes a shift in weather patterns which is a threat to the food production process.

Furthermore, climate change affects crop yields by decreasing productivity (Perdinan et al. 2008, Surmaini et al. 2011). The current system of national rice production is vulnerable to climate change. Also, rice production is predicted to decrease by around $20-30 \%$ in 2030 (A et al. 1996). Besides, climate uncertainties such as floods, drought, and pests can have an impact, both directly and indirectly, on the level of crop failure (PSEKP, 2012).
One way to manage risk in agriculture is through the implementation of crop insurance (Kahan, 2008). This has been widely applied in many countries in favor of small farmers. The lessons emerging from the review of crop insurance in various countries are that some forms are not necessary for encouraging the growth of farm production, and the government support in this endeavor is unavoidable (Pasaribu, 2010). Despite the existing subsidies, price, and other policies that improve farmers' terms of trade, access to inputs and markets, policies responding to risks are clearly lacking. In response to that condition, the government (GoI) implement crop insurance as one of the programs mandated by Law Number 19 of 2013 regarding Farmer Protection and Empowerment. To carry out this mandate, the GoI launched a program known as Rice Farmers Business Insurance (AUTP) in 2015. In the implementation, the GoI through the Ministry of StateOwned Enterprises then appointed PT Asuransi Jasa Indonesia (Persero), a state-owned enterprise, as the administrator. The benefit of this program is to protect for one planting season to paddy farmers with a sum insured of IDR6 million per hectare and a premium of IDR180,000. Considering that the premium paid by farmers might be too expensive, the GoI then provided premium subsidies of $80 \%$ for farmers to only pay IDR36,000. Although the government provided a substantial premium subsidy to increase participation in AUTP, since its launch, farmers' interest to participate is still low. Until 2019, the target of 1 million lands protected by the AUTP set by the GoI each year has not been achieved. This target only saves around $6 \%$ of Indonesia's total agricultural land, which amounts to 15 million hectares.

Table 1. Land protected by AUTP, 2015 - May 2020

\begin{tabular}{ccc}
\hline Year & $\begin{array}{c}\text { Land insured } \\
\text { (hectares) }\end{array}$ & $\begin{array}{c}\text { Land insured } \\
\text { compare to target }\end{array}$ \\
\hline 2015 & 233,499 & $23.3 \%$ \\
2016 & 518,506 & $51.9 \%$ \\
2017 & 997,960 & $99.8 \%$ \\
2018 & 901,420 & $90.1 \%$ \\
2019 & 971,218 & $97.1 \%$ \\
May 2020 & 333,505 & $33.3 \%$ \\
\hline
\end{tabular}

Source: PT Asuransi Jasa Indonesia (Persero) (June 2020), recalculated. 
Literature suggests the existence of a positive, although inelastic, effect of the subsidy level on demand for crop insurance (Goodwin et al. 2004, Lavorato et al. 2019). Meanwhile, higher premium subsidies induce more insurance coverage, lowering farmers' risk ( $\mathrm{Yu}$ et al. 2017). Also, changes in support may only impact the level of total premiums and liabilities per hectare, but not the farmer participation level (O'Donoghue, 2014). Therefore, to maintain high participation and coverage levels, the government premium subsidies would need to be higher in riskier farm areas (Yi et al. 2016), leading to the adverse-selection issue.

Regarding how much is the suitable figure of premium subsidies, most farmers will not pay even close to actuarially fair premium rates for crop insurance because they believe they can effectively use the funds in other ways (Smith, 2016). The study conducted by Babcock et al. (2004) showed that even when $65 \%$ premiums are actuarially fair, $75 \%$ are still too high for most farmers, leading to higher government spending for the subsidies. In the US, the federal crop insurance program has risen to the point that it is the most expensive form of intervention in agricultural markets due to the high premium subsidies (Goodwin and Smith, 2013). The federal crop insurance program could induce welfare loss because it undermines economic efficiency (Ye et al. 2009). However, premium subsidies do not always cause farmers to produce more output (Ye et al. 2009), and it is not different in Indonesia. Even though the subsidies are high, the effect on the crop insurance participation level is still low. Farmers even demand higher premium subsidies than the current scheme (Ambarawati, 2018).

In addition to providing these subsidies, in specific periods, the GoI also integrated other programs with AUTP, such as subsidized fertilizer and a high-quality seed program positioned as an intervention action. In those programs, farmers are required to participate in AUTP as a condition. However, despite those efforts, their interest is still low. Therefore, To investigate the characteristics of farmers who participate and those that do not, studies were conducted to analyze the socio-economic factors that determine farmers' participation in crop insurance (Siswadi and Syakir, 2016; Azriani et al. 2018; Marphy and Priminingtyas, 2019). However, those studies only acknowledge the first layer intervention, the premium subsidies, without considering other GoI program's effects as the second layer.
This study fills the research gap of not considering the GoI program as the second layer intervention. Therefore, this study aimed to investigate the effect of the GoI programs that require participation in AUTP as a prerequisite for redeeming subsidized fertilizer implemented in 2019. The GoI program stopped in 2020 , which led to a decrease in farmer participation. Furthermore, this study aimed to investigate the effect of a government intervention program on AUTP participation level and ascertain the socio-economic factors that influence farmers to participate when the program is implemented and when it is not. This research was conducted in the Sliyeg subdistrict, Indramayu Regency, West Java. This province is the 2nd largest national rice granary, with Indramayu as the highest contributor. Meanwhile, Sliyeg is one of the highest rice producers in Indramayu, with a population of 58,454 , and $15 \%$ of them are paddy farmers, which makes it fit for this research.

\section{METHODS}

The population of this study was 8,597 paddy farmers in Sliyeg (BPS, 2018). This study used a descriptive approach through primary data obtained by questionnaires distributed to 110 farmers of landowners and tenants in 14 villages in Sliyeg as the unit of analysis. Furthermore, samples were taken by the purposive sampling method, and respondent determining was conducted by simple random sampling. Meanwhile, filling out the questionnaire was carried out from March 23 to April 6, 2020, using the direct interview method. The total number of returned and completed questionnaires were 103. The respondents were asked if they have ever participated in AUTP and whether they still participated when terminated the government program.

First, the farmer's participation in AUTP will be processed using Multiple Regression Analysis to investigate the influence of the farmers' socioeconomic as independent variables to farmers' AUTP participation experience as the dependent variables as pictured in Figure 1. The hypothesis for this test is that all independent variables, individually or simultaneously, influence the dependent variables and the test will use the following formula:

$$
\mathrm{Y}=\beta_{0}+\beta_{1} \mathrm{X}_{1}+\beta_{2} \mathrm{X}_{2}+\ldots \beta_{8} \mathrm{X}_{8}+\varepsilon
$$


where $\mathrm{Y}$ is farmers' AUTP buying experience whether ever or never bought AUTP and $X_{1}$ until $X_{8}$ are the farmers' socio-economic consist of age, sex, level of education, marital status, number of dependents, land ownership status, farming experience and land size.

The data were then processed using the McNemar Test with the following formula:

$$
\chi^{2}=(|\mathrm{A}-\mathrm{D}|-1)^{2} /(\mathrm{A}+\mathrm{D})
$$

Where A and D were the change of behavior when enforced the GoI program and after termination. The objective of the McNemar Test is to determine whether there was an effect of farmers' participation in AUTP when implemented the GoI program and when it was terminated with the following hypothesis:

$\mathrm{H} 0$ : There is no effect on participation level with and without a government program.

H1 : There is an effect on participation level with and without a government program.

The decision-making criteria for the McNemar test was as follows: If calculated $\mathrm{Z}<\mathrm{Z}$ table and significant value $>0.05$ then $\mathrm{H} 0$ is accepted; If calculated $\mathrm{Z}>\mathrm{Z}$ table and significant value $<0.05$ then $\mathrm{H} 0$ is rejected. Meanwhile, ascertain the socio-economic factors that influence farmers to participate or not in the AUTP with or without GoI program,

$$
\left\{\begin{array}{l}
\text { 1,if participate in AUTP } \\
0, \text { if not participate in AUTP }
\end{array}\right.
$$

Logistic Regression Analysis then used given by:

$$
\log _{\mathrm{it}}(\rho)=\ln (\rho /(1-\rho))=\beta_{0}+\beta_{1} \mathrm{X}_{1}+\beta_{2} \mathrm{X}_{2}+\ldots \beta_{8} \mathrm{X}_{8}
$$

$\mathrm{X}_{1}$ until $\mathrm{X}_{8}$ are the farmers' socio-economic consist of age, sex, level of education, marital status, number of dependents, land ownership status, farming experience and land size. Age and land size variables are those with ratio data types used to facilitate the analysis results' interpretation. The categories created is seen in the descriptive statistics section. Also, the interpretation used in the logit regression model was to use the odds ratio, and the SPSS output was displayed in the $[\exp (\beta)]$ column. The odds ratio explains how many increases or decreases in the farmer's probability to participate in the AUTP program when the value of the independent variable $(X)$ changes by a certain value.

\section{RESULTS}

\section{Socio-economics Characteristics of the Respondents}

The socio-economic characteristics of farmers were used as indicators of their ability to carry out economic activities. The descriptive statistics in Table 3 showed the respondents are mostly male in the productive age with the age range of 40-49 and 50-59. Most of the respondents are married with 2 to 4 dependents. Furthermore, $42 \%$ have completed high school, and $41 \%$ only completed elementary education. Almost all respondents have more than five years of farming experience and are mostly landowners with 1 hectare or less.

The result in Table 4 shows that the only farmers' socioeconomics characteristics that significantly influenced the participation in AUTP are land ownership status. This condition might have happened because the insurance company will only cover the land in one expanse regardless of the farmer's characteristics. Every farmer will have peer pressure to participate in AUTP if the majority of the expanse is participating.

\begin{tabular}{|l|l|}
\hline Independent Variables & Dependent Variables \\
(X1) Age & (Y) Participation in AUTP \\
(X2) Sex & \\
(X3) Level of Education & \\
(X4) Marital Status & \\
(X5) Number of Dependents & \\
(X6) Land Ownership Status & \\
(X7) Farming Experience & \\
(X8) Land Size & \\
\hline
\end{tabular}

Figure 1. Research framework 
Table 3. Descriptive Statistics

\begin{tabular}{|c|c|c|c|}
\hline Variable & Category & Total & Percentage $(\%)$ \\
\hline \multirow[t]{5}{*}{ Age } & $<30$ & 2 & 1.9 \\
\hline & $30-39$ & 10 & 9.7 \\
\hline & $40-49$ & 37 & 35.9 \\
\hline & $50-59$ & 37 & 35.9 \\
\hline & $\geq 60$ & 17 & 16.5 \\
\hline \multirow[t]{2}{*}{ Sex } & Male & 99 & 96.1 \\
\hline & Female & 4 & 3.9 \\
\hline \multirow{3}{*}{$\begin{array}{l}\text { Level of } \\
\text { Education }\end{array}$} & Elementary & 41 & 39.8 \\
\hline & Junior High & 20 & 19.4 \\
\hline & High School & 42 & 40.8 \\
\hline \multirow{2}{*}{$\begin{array}{l}\text { Marital } \\
\text { Status }\end{array}$} & Married & 100 & 97.1 \\
\hline & Single & 3 & 2.9 \\
\hline \multirow{8}{*}{$\begin{array}{l}\text { Number of } \\
\text { Dependents }\end{array}$} & 0 & 2 & 1.9 \\
\hline & 1 & 11 & 10.7 \\
\hline & 2 & 27 & 26.2 \\
\hline & 3 & 27 & 26.2 \\
\hline & 4 & 24 & 23.3 \\
\hline & 5 & 7 & 6.8 \\
\hline & 6 & 3 & 2.9 \\
\hline & 7 & 2 & 1.9 \\
\hline \multirow{2}{*}{$\begin{array}{l}\text { Land } \\
\text { Ownership } \\
\text { Status }\end{array}$} & Land Tenant & 40 & 38.8 \\
\hline & Landowner & 63 & 61.2 \\
\hline \multirow{2}{*}{$\begin{array}{l}\text { Farming } \\
\text { Experience }\end{array}$} & $1-5$ years & 7 & 6.8 \\
\hline & $>5$ years & 96 & 93.2 \\
\hline \multirow{5}{*}{$\begin{array}{l}\text { Land Size } \\
\text { (ha) }\end{array}$} & $<=0,5$ & 45 & 43.7 \\
\hline & $>0,5-1$ & 42 & 40.8 \\
\hline & $>1-1.5$ & 4 & 3.9 \\
\hline & $1.5-2$ & 8 & 7.8 \\
\hline & $>2$ & 2 & 1.9 \\
\hline
\end{tabular}

Table 4. Multiple Regression result of participation in AUTP

\begin{tabular}{lccc}
\hline Independent Variables & $\begin{array}{c}\text { Std Coeff. } \\
\text { Beta }\end{array}$ & $\mathrm{t}$ & Sig. \\
\hline Age & -0.14 & -1.30 & \\
Sex & 0.01 & 0.14 & \\
Level of Education & -0.17 & -1.44 & \\
Marital Status & -0.04 & -0.37 & \\
No. of Dependent & -0.09 & -0.88 & \\
Land Ownership Status & -0.21 & -2.05 & $*$ \\
Farming Experience & -0.09 & -0.94 & \\
Land Size & 0.17 & 1.53 & \\
\hline
\end{tabular}

The symbol $(*)$ in the Sig. column indicates a variable that has a significant effect on the error level of $10 \%$, i.e. the p-value is smaller than 0.10 .

\section{Effect of the Government Program on the AUTP Participation}

Data from the questionnaires (Table 5) were converted to the following format for McNemar test (Table 6). From the test, the result of the calculated $Z$ was 24.083 with a significance value of $0 \%$, while $Z$ table was 3.841 with a significance value of $5 \%$ and $\mathrm{df}=1$. As the calculated $\mathrm{Z}>\mathrm{Z}$ table and significant value $<0.05$, then $\mathrm{H} 0$ is rejected. Hence, there is an effect in participation level with and without a government program.

\section{Analysis of Participation in AUTP with Government Program}

From the logistic regression analysis, based on the results in the Table 7, two independent variables have a significant influence on AUTP participation when enforced the government program. These variables are Land Ownership Status and Land Size for the category of $>1.5-2$ hectares.

Land Ownership Status

This variable has two categories, which are land tenants and landowners. The odds ratio $[\exp (\beta)]$ of this variable is 0.31 which can be interpreted that the landowners have a $31 \%$ lower possibility to participate in AUTP when the government program was enforced. Meanwhile, land tenant farmers have a 3.2 times higher probability of participating when the program was enforced.

Table 5. Farmer Participation in AUTP

\begin{tabular}{llcc}
\hline & & \multicolumn{2}{c}{ Without } \\
& & $\begin{array}{c}\text { Not } \\
\text { Participate }\end{array}$ & Participate \\
\hline $\begin{array}{l}\text { With } \\
\text { Government } \\
\text { Program }\end{array}$ & $\begin{array}{l}\text { Not } \\
\text { Participate }\end{array}$ & 57 & 0 \\
\hline & Participate & 26 & 20 \\
Table 6. McNemar Test Result & \\
\hline \multicolumn{3}{c}{ With and Without } \\
& & Government Program \\
\hline N & \multicolumn{2}{c}{103} \\
Chi-Square & \multicolumn{2}{c}{24.083} \\
Asymp. Sig. & \multicolumn{2}{c}{.000} \\
\hline
\end{tabular}


Table 7. Logistic Regression result of participation in AUTP with government program

\begin{tabular}{lcccc}
\hline Independent Variables & $\beta$ & $\operatorname{Exp}(\beta)$ & $\mathrm{p}$-calc & Sig. \\
\hline Age & & & & \\
$\quad(30-39)$ & -20.01 & 0.00 & 0.99 & \\
$(40-49)$ & -20.17 & 0.00 & 0.99 & \\
$(50-59)$ & -20.63 & 0.00 & 0.99 & \\
$\quad(>=60)$ & -20.41 & 0.00 & 0.99 & \\
Sex & 0.47 & 1.59 & 0.68 & \\
Level of Education & & & & \\
$\quad($ SMP) & -0.76 & 0.47 & 0.24 & \\
$\quad$ SMA) & -0.70 & 0.49 & 0.24 & \\
Marital Status & -0.21 & 0.81 & 0.89 & \\
No. of Dependent & -0.19 & 0.82 & 0.27 & \\
Land Ownership Status & -1.17 & 0.31 & 0.02 & $*$ \\
Farming Experience & -1.09 & 0.34 & 0.27 & \\
Land Size (ha) & & & & \\
$\quad(0.5-1)$ & 0.77 & 2.16 & 0.14 & \\
(>1 - 1.5) & 0.79 & 2.22 & 0.49 & \\
(>1.5 - 2) & 2.09 & 8.15 & 0.03 & $*$ \\
(> 2) & 0.61 & 1.85 & 0.70 & \\
\hline
\end{tabular}

The symbol $(*)$ in the Sig. column indicates a variable that has a significant effect on the error level of $10 \%$, i.e. the $\mathrm{p}$-value is smaller than 0.10 .

\section{Land Size of $>1.5-2$ hectares}

The Land Size variable has five categories, and farmers with land size of 0.5 hectares and below are the basis of comparison. Meanwhile, the odds ratio $[\exp (\beta)]$ of the land size variable of $1.5-2$ hectares is 8.15 . This means that farmers with 1.5-2 hectares of land have an $815 \%$ (8.15 times) higher possibility to participate compared to those with 0.5 hectares and below.

\section{Analysis of Participation in AUTP without Government Program}

Based on the results in the Table 8 , there is only one independent variable that has a significant effect on AUTP participation when the government program was stopped, which is the Land Size for the category of more than 1.5 up to 2 hectares.

Land Size of $>1.5-2$ hectares

The Land Size variable has five categories, and farmers with a land size of 0.5 hectares and below are the basis of comparison. Meanwhile, the odds ratio $[\exp (\beta)]$ of the land size variable $>1.5-2$ hectares is 21.77 . This means farmers with $>1.5-2$ hectares of land have a $2,177 \%$ ( 21.77 times) higher probability of participating when stopped the government program than those with a land size of 0.5 hectares and below.

\section{The Effect of Government Program to Stimulate Farmer Participation in AUTP}

Based on the result, the government intervention program and crop insurance premium subsidy are proven to have a positive and significant effect of stimulating farmer participation in AUTP. Hence, it could be stated that the premium subsidy alone is not sufficient to boost participation. The government also needs to provide other intervention programs to complement the premium subsidy to increase the participation rate. Studies about the effect of the intervention program in addition to crop insurance premium subsidy have not been conducted. Therefore, considering the premium subsidy and other programs are part of the public intervention, this research confirmed the previous study conducted by Goodwin et al. (2004) and Lavorato et al. (2019) that showed premium subsidy has a positive effect on the crop insurance demand. In line with the positive impact, it is unavoidable that farmers will demand a higher subsidy than the current scheme, as confirmed by Ambarawati (2018). Also, According to Smith (2016), farmers believe that they can use the funds they pay for the insurance effectively in other ways. Meanwhile, a study conducted by Babcock et al. (2004) showed that even when $65 \%$ of premiums are actuarially fair, $75 \%$ are still too high for most farmers.

Hence, other intervention programs might be a good solution to avoid close to zero farmers' contribution to pay for the crop insurance premium. With this program, the government will help farmers to focus on risk and also productivity. Also, they need to see crop insurance as part of a comprehensive risk management framework to modernize agriculture. This should be promoted together with other basic agricultural services such as timely availability of inputs, extension services, and efficient marketing channels for the outputs. In the future, rather than increase the premium subsidy, it will be beneficial for the government to provide a complementary program to support the end-to-end production process and place crop insurance as an important component. 
Table 8. Logistic Regression result of participation in AUTP without GoI program

\begin{tabular}{lcccc}
\hline Independent Variables & $\beta$ & $\operatorname{Exp}(\beta)$ & $\mathrm{p}$-calc & Sig. \\
\hline Age & & & & \\
$(30-39)$ & -19.76 & 0.00 & 0.99 & \\
$(40-49)$ & 0.80 & 2.24 & 0.76 & \\
$(50-59)$ & -0.43 & 0.65 & 0.87 & \\
$(>=60)$ & -0.75 & 0.47 & 0.78 & \\
Sex & -0.28 & 0.75 & 0.82 & \\
Education & & & & \\
$\quad$ SMP) & -0.24 & 0.78 & 0.77 & \\
$\quad$ SMA) & -0.96 & 0.38 & 0.24 & \\
Marital Status & 0.19 & 1.21 & 0.95 & \\
No. of Dependent & -0.38 & 0.68 & 0.14 & \\
Land Ownership Status & -0.19 & 0.83 & 0.76 & \\
Farming Experience & -0.89 & 0.41 & 0.42 & \\
Land Size (ha) & & & & \\
$\quad(0.5-1)$ & 0.47 & 1.60 & 0.51 & \\
$(>1-1.5)$ & 0.48 & 1.62 & 0.73 & \\
$(>1.5-2)$ & 3.08 & 21.77 & 0.01 & $*$ \\
$(>2)$ & 1.57 & 4.79 & 0.35 & \\
\hline
\end{tabular}

The symbol $(*)$ in the Sig. column indicates a variable that has a significant effect on the error level of $10 \%$, i.e. the $\mathrm{p}$-value is smaller than 0.10 .

\section{The Socioeconomic Factors that Influence Farmers to Participate in AUTP}

Previous studies conducted by Siswadi and Syakir (2016), Azriani et al. (2018), Marphy and Priminingtyas (2019) found that age, education, farming experience, income, farm group membership and land size are the factors that influence farmers to participate in AUTP. Although, their study did not consider the second layer government intervention program. This research confirmed that land size is one of the socio-economic factors that influence farmers to participate when the government program was enforced and terminated. Furthermore, it was found that land ownership status, specifically for the land tenant, is an influencer factor to participate in when the government program was enforced. From the result shown in Table 7 and Table 8 , we can also see that the influencers are not related to the farmer's personal attributes but more to the object of coverage, the land.

\section{Managerial Implications}

This study shows that the level of farmer participation in AUTP is influenced by the pull strategy, such as premium subsidy programs and encouraging or coercive programs. An example of a government program that is encouraging or coercive is a program discussed in this research, namely by making AUTP a condition to redeem subsidized fertilizers. With the low level of crop insurance awareness and insurance in general, this research results proved that encouraging or coercive programs are effective to increase farmers' participation in AUTP. For this reason, the government needs to continue a similar program to increase farmers' awareness of crop insurance. When creating the program, refer to the findings from this research. The government should target land tenants with a land size of more than 1.5 up to 2 hectares as they have a higher awareness of crop insurance than others.

\section{CONCLUSIONS AND RECOMMENDATIONS}

\section{Conclusions}

Based on the study findings, it can conclude that the GoI program that requires AUTP as a prerequisite for redeeming subsidized fertilizer affects farmers' participation level. Meanwhile, this level is higher when the government program was enforced and decreased when it was terminated. The socio-economics variables that influence a farmer to participate in AUTP when enforced the government program are land ownership status, specifically for the tenant and land size for those with more than 1.5 up to 2 hectares of land. Furthermore, when terminated the program, the socio-economics variables that influence farmers to participate is the land size for those with more than 1.5 up to 2 hectares of land.

\section{Recommendations}

In studying the participation level, especially for a crop insurance product, research needs to investigate other intervention programs attached to the product to avoid bias. Furthermore, future research needs to compare the different intervention programs' effectiveness to the farmers' participation level in crop insurance.

\section{ACKNOWLEDGEMENT}

The authors would like to thank for field agriculture instructors and anonymous respondents in Sliyeg subdistrict. Their expression towards the content of research was meaningful to the implementation of the crop insurance program. 


\section{REFERENCES}

Ambarawati IGAA, Wijaya IMAS, Budiasa IW. 2018. Risk mitigation for rice production through agricultural insurance: farmer's perspectives. Jurnal Manajemen \& Agribisnis 15(2):129-135. https://doi.org/10.17358/jma.15.2.129

Amien I, Rejekiningrum P, Pramudia A, Susanti E. 1996. Effects of interannual climate variability and climate change on rice yield in Java, Indonesia. Journal of Water, Air, and Soil Pollution 92: 2939. https://doi.org/10.1007/978-94-017-10534_3.

Azriani Z, Refdinal, Paloma C. 2018. Pelaksanaan Asuransi Usaha Tani Padi dalam meningkatkan ketahanan pangan di kota Padang. Prosiding. Seminar Nasional dalam rangka Dies Natalis UNS ke-42 tahun 2018. Universitas Sebelas Maret. Solo. Valume 2, Number 1, Pages 36-43.

Babcock BA, Hart CE, Hayes DJ. 2004. Actuarial Fairness of Crop Insurance Rates with Constant Rate Relativities. American Journal of Agricultural Economics 86(3): 563-575.https:// doi.org/10.1111/j.0002-9092.2004.00601.x.

BPS Kabupaten Indramayu. 2018. Kecamatan Sliyeg dalam angka 2018. Indramayu: CV Memory.

[FAO] Food and Agriculture Organization of the United Nations. 2020. Food outlook: biannual report on global food markets. Rome: FAO.

Goodwin BK, Smith VH. 2013. What harm is done by subsidizing crop insurance? American Journal of Agricultural Economics 95(2): 489-497.

Goodwin BK, Vandeveer ML, Deal J L. 2004. An Empirical Analysis of Acreage Effects of Participation in the Federal Crop Insurance Program. American Journal of Agricultural Economics 86(4): 1058-1077.https://doi. org/10.1093/ajae/aas092.

Kahan D. 2008. Managing Risk in Farming. Food and Agriculture Organization (FAO), Rome.

Lavorato MP, Costa LLV, Braga MJ. 2019. Premium subsidies and crop insurance demand in Brazil. Agricultural Finance Review 80(1):134-148. https://doi.org/10.1108/AFR-10-2018-0082.

Marphy TM, Priminingtyas DN. 2019. Analisis faktorfaktor yang mempengaruhi tingkat partisipasi petani dalam program Asuransi Usaha Tani Padi (AUTP) di Desa Watugede, Kecamatan Singosari,
Kabupaten Malang. Habitat 30(2):62-70. https:// doi.org/10.21776/ub.habitat.2019.030.2.8.

O'Donoghue E. 2014. The effects of premium subsidies on demand for crop Insurance. Economic Research Report 178405, United States Department of Agriculture, Economic Research Service.

Pasaribu SM. 2010. Developing rice farm insurance in Indonesia. Prosiding. International Conference on Agricultural Risk and Food Security 2010. Agriculture and Agricultural Science Procedia 1:33-41. https://doi.org/10.1016/j. aaspro.2010.09.005.

Perdinan, Boer R, Kartikasari K. 2008. Linking climate change adaptation option for rice production and sustainable development in Indonesia. Jurnal Agromet 22(2):94-107. https://doi. org/10.29244/j.agromet.22.2.94-108.

[PSEKP] Pusat Analisis Sosial Ekonomi Kebijakan Pertanian. 2012. Pengembangan Asuransi Usaha Tani Padi untuk antisipasi perubahan iklim. Warta Penelitian dan Pengembangan Pertanian 34(2):16-18.

Siswadi B, Syakir F. 2016. Respon petani terhadap program pemerintah mengenai Asuransi Usaha Tani Padi (AUTP). Prosiding. Seminar Nasional Pembangunan Pertanian 2016. Malang:Universitas Brawijaya.

Smith, VH. 2016. Limiting premium subsidies for crop insurance. $R$ Street Policy Study 61:1-24.

Surmaini E, Runtunuwu E, Las I. 2011. Upaya sektor pertanian dalam menghadapi perubahan iklim. Jurnal Litbang Pertanian 30(1):1-7. http:// dx.doi.org/10.21082/jp3.v30n1.2011.p1-7.

[USDA] United States Department of Agriculture. 2020. Global Market Analysis. Foreign Agricultural Service August 2020: 8-25.

Yi J, Richardson JW, Bryant HL. 2016. How do premium subsidies affect crop insurance demand at different coverage levels: the case of corn. Selected Poster/Paper prepared for presentation at the Agricultural \& Applied Economics Association's 2016 AAEA Annual Meeting, Boston, Massachusetts, July 31-August 2, 2016.

Yu J, Smith A, Sumner DA. 2017. Effects of Crop Insurance Premium Subsidies on Crop Acreage. American Journal of Agricultural Economics 100(1):91-114. https://doi.org/10.1093/ajae/ 
aax058.

Ye T, Yokomatsu M, Okada N. 2009. Premium subsidy for crop insurance as an incentive device in
China: In which respects might it work wrongly? Journal of Natural Disaster Science 31(2): 3-12. https://doi.org/10.2328/jnds.31.39. 